Videre skriver medisinhistoriker Aina Schiøtz at Evang spilte «en viktig rolle i det forberedende arbeidet med hensyn til kriminalisering av feltet» (7). Hvorvidt det var reell uenighet mellom Evang og Justisdepartementet, er et interessant spørsmål som gjerne kan belyses ytterligere.

For øvrig er jeg glad for at også Waal \& Mørland ønsker en reformert narkotikapolitikk velkommen, og at de også trekker frem at det er lite forskningsmessig støtte for kriminalisering. Et første steg for norsk politikk bør være å avkriminalisere bruk, besittelse og salg av mindre mengder narkotika og å styrke medisinske og sosiale alternativer til juridiske sanksjoner (8).

\section{Ketil Slagstad}

ketil.slagstad@tidsskriftet.no

Ketil Slagstad (f. 1983) er lege og medisinsk redaktør i Tidsskriftet. Ingen oppgitte interessekonflikter.

\section{Litteratur}

1. Waal H, Mørland J. Stoff, straff og sosial smitte - en uheldig sammenblanding. Tidsskr Nor Legeforen 2017; 137: 262

2. Slagstad K. Stoff, straff og sosial smitte. Tidsskr Nor Legeforen 2016; 136: 1871.

3. Evang K. Narkotika, generasjonene og samfunnet. 2. utg. Oslo: Tiden, 1974: 16

4. Evang K. Narkotika, generasjonene og samfunnet. 2. utg. Oslo: Tiden, 1974: 180 Slagstad R. De nasjonale strateger. Oslo: Pax forlag, 1998

5. Slagstad R. De nasjonale strateger. Oslo: Pax forlag, 1998. www.forebygging.no/Global/KonseptualiseringSkretting_rev.pdf (29.1.2017).

7. Schiøtz A. Rus og rusmiddelpolitikk i Norge: Et historisk tilbakeblikk. Oslo: Den norske legeforening, 2012

8. Csete J, Kamarulzaman A, Kazatchkine M et al. Public health and international drug policy. Lancet 2016; 387: 1427-80.

J. Ræder og medarbeidere hadde i Tidsskriftet nr. 18/2016 en artikkel om utfasing av ketobemidon til bruk på sykehus til fordel for morfin eller oksykodon. Det har avfødt en del debatt du kan lese på våre nettsider. Vi bringer her siste innlegg i diskusjonen.

\section{Re: Fra ketobemidon til oksykodon}

Takk til Ræder og medarbeidere (1) for utfyllende opplysninger. Vi verken var eller er uenige i at $30 \%$-forskjellen i farmakologisk potens mellom preparatene er klinisk vesentlig. Morfin kan gis som akutt kortvarig behandling til de fleste pasienter, men forsiktighet bør utvises ved alvorlig nyresvikt. Dette er de fleste norske leger klar over. Vi er også enige om at det er fornuftig å tilstrebe enkle prosedyrer ved medikamentskifte, men kan ikke se det er et relevant argument for å velge morfin eller oksykodon. Vi er enige $i$ at oksykodon intravenøst mest sannsynlig har raskere anslag enn morfin, men det er ingen overbevisende studier på at det medfører klinisk meningsfull forskjell. Tvert imot har vi selv vist at intravenøst morfin virker allerede etter fem minutter, tilstrekkelig raskt for effektiv titrering (2). Når det gjelder peroralt oksykodon, er det eksperimentelle holdepunkter for at oksykodon utviser en betydelig absorpsjonsforsinkelse (3) uten at den kliniske betydningen av dette er kjent. Vi er uenige i at større biotilgjengelighet per se gir større forutsigbarhet, og vil ikke legge avgjørende vekt på modellerende humane, eksperimentelle smertestudier (3). Eksperimentelle data kan ikke overføres direkte til klinikken. Eksempelvis har CYP2D6polymorfismer hatt betydning for oksykodonvirkning i eksperimentelle, men ikke i kliniske smertestudier $(4,5)$. Vi er glade for Ræder og medarbeideres klare oppfordring til å bruke morfin ved kronisk kreftsmerte, i palliative omsorg, til barn (foreløpig) og pasienter med økt fare for misbruk (1). Avslutningsvis lar vi Olkkola og medarbeideres ord bli våre (4): «Our current understanding of the pharmacology of oxycodone does not explain the significant increase in its clinical use.» For vår del avslutter vi debatten her.

Ola Dale

ola.dale@ntnu.no

Pål Klepstad

Torkjel Tveita

Just Thoner

Petter C. Borchgrevink
Ola Dale (f. 1948) er professor ved Norges teknisk-naturvitenskapelige universitet/St. Olavs hospital.

Ingen oppgitte interessekonflikter.

Pål Klepstad (f.1962) er avdelingssjef ved Hovedintensiv, St Olavs hospital og professor ved Norges teknisk-naturvitenskapelige universitet. Ingen oppgitte interessekonflikter.

Torkjel Tveita (f. 1951) er overlege og professor ved Anestesi- og operasjonsavdelingen, Universitetssykehuset i Nord-Norge.

Ingen oppgitte interessekonflikter.

Just Thoner (f.1948) er overlege ved OPIN-klinikken, Universitetssykehuset i Nord-Norge.

Ingen oppgitte interessekonflikter.

Petter C. Borchgrevink (f. 1952) er avdelingssjef ved Avdeling for smerte og sammensatte lidelser, St. Olavs hospital og/professor ved Norges teknisk-naturvitenskapelige universitet. Ingen oppgitte interessekonflikter.

\section{Litteratur}

1. Ræder J, Dahl V, Markestad A et al. Re: Fra ketobemidon til morfin eller oksykodon. Tidsskr Nor Legeforen 2017: 137: 170.

2. Tveita $T$, Thoner J, Klepstad $P$ et al. A controlled comparison between single doses of intravenous and intramuscular morphine with respect to analgesic effects and patient safety. Acta Anaesthesiol Scand 2008; 52: 920-5.

3. Staahl C, Upton R, Foster DJ et al. Pharmacokinetic-pharmacodynamic modeling of morphine and oxycodone concentrations and analgesic effect in a multimodal experimental pain model. J Clin Pharmacol 2008; 48: 619-31.

4. Olkkola KT, Kontinen VK, Saari TI et al. Does the pharmacology of oxycodone justify its increasing use as an analgesic? Trends Pharmacol Sci 2013; 34: $206-14$

5. Andreassen TN, Eftedal I, Klepstad P et al. Do CYP2D6 genotypes reflect oxy codone requirements for cancer patients treated for cancer pain? A cross-sec tional multicentre study. Eur J Clin Pharmacol 2012; 68: 55-64.

\section{Re: Én pasient, to verdener - samhandling mellom sykehjemsleger og sykehusleger}

Takk til M. Romøren og medarbeidere for artikkelen «Én pasient, to verdener - samhandling mellom sykehjemsleger og sykehusleger» i Tidsskriftet nr. 3/2017 (1). Undertegnede valgte artikkelen som bakgrunn for diskusjon om samhandling i en smågruppe for sykehjemsmedisin som jeg deltar i sammen med fem andre sykehjemsleger. Vi er ansatt ved sykehjem i kommunene Bærum og Oslo.

Ved gjennomlesning av artikkelen kunne vi alle kjenne oss igjen på flere områder. Det stemmer, som forfatterne påpeker, at det er rom for forbedring i samarbeidet mellom sykehusleger og sykehjemsleger. Heldigvis opplever mine kolleger og jeg at forholdene er noe bedre i våre kommuner enn det som er beskrevet i artikkelen. Jeg tror noe av forklaringen til dette er at flertallet av legene som ble intervjuet i studien var fastleger som hadde tilsynsvirksomhet ved sykehjem i $20 \%$ stilling. Når det i tillegg var fast tilstedeværelse kun deler av denne tiden, sier det seg selv at de ikke nødvendigvis tilbrakte nok tid på sykehjemmene for å kunne gi dem den medisinske oppfølgingen de hadde behov for. I både Oslo og Bærum har man de siste årene gradvis gått vekk fra denne tilsynslegeordningen og over til å ansette leger i større faste stillinger ved sykehjemmene. Jeg har inntrykk av at dette er en generell tendens i landet for øvrig også, og mener at dette er en positiv utvikling. Vi som velger å jobbe som sykehjemsleger har gjerne et stort engasjement for sykehjemspasienter og de medisinskfaglige og etiske utfordringene man møter på. Personlig foretrekker jeg å bli omtalt som «sykehjemslege» fremfor «tilsynslege» av for eksempel sykepleierne, da mitt inntrykk er at tilsynslegene typisk har utført litt venstrehåndsarbeid i sykehjem, om jeg skal være litt krass. Derfor er benevningen «tilsynslege» for meg blitt et negativt ladet begrep som jeg helst ikke vil assosiere meg med. Jeg vil derfor oppfordre 